\title{
PHOTOVOLTAIC PERFORMANCES OF TWO TRIARYLAMINE-BASED DONORS IN VARIOUS INVERTED CELL CONFIGURATIONS
}

\author{
GAVRIL-IONEL GIURGI ${ }^{\mathrm{a}, \mathrm{b}}$, LORANT SZOLGA ${ }^{\mathrm{a}, \mathrm{b},{ }^{*},}$ \\ ANDREEA CRIȘAN ${ }^{a}$, ION GROSU ${ }^{\mathrm{a},{ }^{*},}$ JEAN RONCALI ${ }^{\mathrm{a},{ }^{*}}$
}

\begin{abstract}
A complex analysis on the photovoltaic capabilities of two triarylamine-thienyl-based donors was conducted using different buffer layers in the structure of the cells, such as $\mathrm{ZnO}$ and $\mathrm{MoO}_{3}$. The photovoltaic properties of the fabricated cells were characterized under simulated solar light, and monochromatic illumination. The analysis revealed a higher power conversion efficiency for the inverted-bulk-heterojunction structures.
\end{abstract}

Keywords: Organic solar cells, bilayer structure, bulk heterojunction, inverted structure, triarylamine derivatives

\section{INTRODUCTION}

Organic photovoltaics (OPV) is a focus of intensive research effort motivated by multiple advantages such as low environmental impact, lowcost, flexibility, lightweight, and possible semi-transparency [1-4].

OPV cells can be fabricated by various techniques including vacuum deposition of bi-layer planar heterojunction $(\mathrm{PHJ})[3,4]$ and solution-processing of bulk heterojunction solar cells (BHJ) [12]. BHJ technology is the most developed and with best results so far but, although PHJ cells were surpassed in terms of power conversion efficiency (PCE) by BHJ cells, they are still valuable in the process of screening new active materials [5]. BHJ cells are fabricated at ambient temperature by spin-casting blend films from solutions of donor (D) and acceptor (A) materials. Two major cell architectures are proposed, a "direct" and an "inverted" one. In a direct cell, the active material

a Babes-Bolyai University, Faculty of Chemistry and Chemical Engineering, Department of Chemistry and SOOMCC, Cluj-Napoca, 11 Arany Janos, 400028, Cluj-Napoca, Romania

b Optoelectronics Group, Base of Electronics Department, ETTI, Technical University of ClujNapoca, Str. Memorandumului, Nr.28, Cluj-Napoca, 400114, Romania

* Corresponding authors: lorant.szolga@bel.utcluj.ro, igrosu@chem.ubbcluj.ro, jeanroncali@gmail.com 
blend of $\mathbf{D}$ with $\mathbf{A}$ is spun-cast or PVD deposited on an indium-tin oxide (ITO) conducting electrode coated with a layer of poly(3,4-ethylenedioxythiophene): polystyrene sulfonate (PEDOT:PSS). A more stable cell could be obtained in an inverted structure in which solution-processed layers of $\mathrm{ZnO}$ and PVD deposited $\mathrm{MoO}_{3}$ are inserted between the electrodes and the active material, replacing the PEDOT:PSS layer. The active layer in this case can be deposited by spin-casting or PVD technique. The literature that deals with direct and inverted cell fabrication underlines a higher efficiency and stability of inverted cells [5-8].

Even if conjugated polymers still represent a major class of donors for solution-processed $\mathrm{BHJ}$ cells, lately a significant contribution to the advance of OPVs was brought by use of small molecules due to their welldefined chemical structure, ease of synthesis and purification along easily tuned properties [9-13]. Triarylamine-based molecules as donors have already shown interesting photovoltaic performances [14-17].

We have recently reported on the synthesis of a dyad named $D C V-C_{60}$ in which the connection between $\mathbf{D}$ block (1) containing a triarylamine-thienyl with an appended dicyanovinyl group and $[6,6]$-phenyl- $\mathrm{C}_{61}$-butyric acid methyl ester $\left(\mathrm{PC}_{61} \mathrm{BM}\right)$ as $\mathbf{A}$ is realized through position 3 of the thiophene moiety. The mentioned D-A dyad was also evaluated as active Single-Molecule Organic Solar Cell (SMOSC) material, tested out in inverted structure giving a cell characteristic of $\mathrm{V}_{\mathrm{oc}}=1 \mathrm{~V}, \mathrm{~J}_{\mathrm{sc}}=2.85 \mathrm{~mA} / \mathrm{cm}^{2}, \mathrm{FF}=28 \%$ and $P C E$ of $0.8 \%$ [14]. An analysis of bilayer and $\mathrm{BHJ}$ structures involving the donor 1 was not performed so far. To test if the presence of a hydroxymethyl group at the 3-positio of the thiophene unit would influence the characteristics of resulting cells, we have also synthesized the already reported unsubstituted compound $\mathbf{2}$ for comparison. In the case of donor $\mathbf{2}$, only a direct bilayer analysis was reported previously [17].

In this context, the present work shows a comparative analysis of the cells fabricated in two different structures using the small molecular donors (1) and (2) and fullerene $\left(\mathrm{C}_{60}\right)$ or $\mathrm{PC}_{61} \mathrm{BM}$ as acceptor (Figure 1). Donors 1 and 2 were selected for their accessible synthesis and relevant properties among other small donors obtained in our group [15] [16].
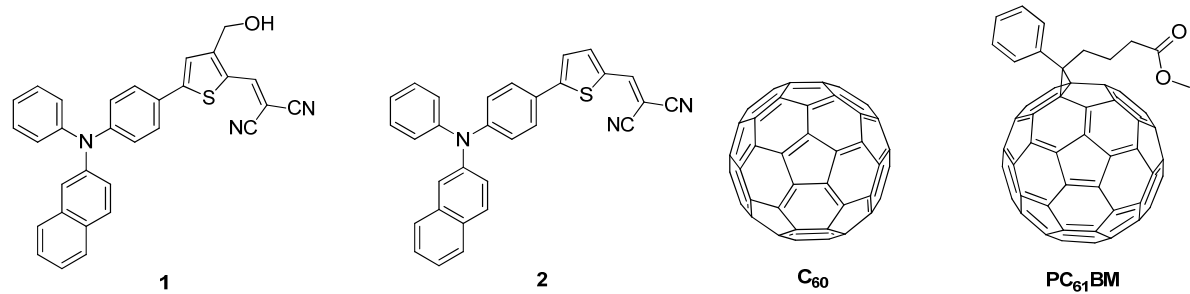

Figure 1. Chemical structures for donors (1 and 2$)$ and the acceptors

( $\mathrm{C}_{60}$ and $\left.\mathrm{PC}_{61} \mathrm{BM}\right)$ 


\section{RESULTS AND DISCUSSIONS}

Figure 2 shows the two structures investigated in the present work: inverted-bilayer and inverted-BHJ. For both structures (bilayer and bulk), two buffer layers were used: a $\mathrm{ZnO}$ one with high capability for electron transport to the ITO electrode and $\mathrm{M} \mathrm{MoO}_{3}$ one as hole-transport layer to the $\mathrm{Al}$ electrode. At the same time, the $\mathrm{MoO}_{3}$ presents very good properties for the encapsulation of the cells, protecting the active layer from the outside environment. Layers of $\mathrm{C}_{60}, \mathrm{MoO}_{3}$ and $\mathrm{Al}$ were always deposited in the vacuum by PVD (Physical Vapor Deposition) technique. The active layer in the case of the BHJ structures was deposited by spin-coating from solution and for the bilayer structures, donors 1 and 2 were deposited by PVD.
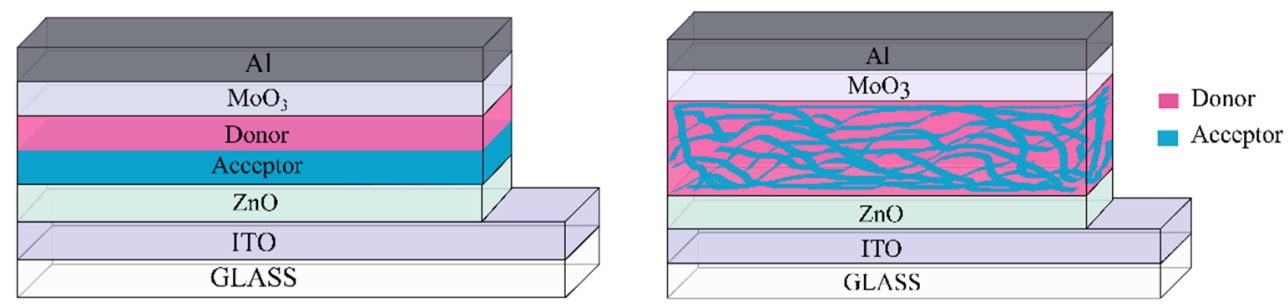

Figure 2. Simplified representations the OSC structures: inverted-bilayer (left) and inverted-BHJ (right)

\section{Inverted-bilayer structure (ITO/ZnO/C $\left.60 / D_{0 n o r} / \mathrm{MoO}_{3} / \mathrm{Al}\right)$}

To test out the inverted structures we spun-cast in each case a $30 \mathrm{~nm}$ layer of $\mathrm{ZnO}$ on the ITO. The next layers were successively vacuum deposited using a thickness of $30 \mathrm{~nm}$ of $\mathrm{C}_{60}$ followed up by a layer of $20 \mathrm{~nm}$ of donor. The active layer was covered by a $10 \mathrm{~nm}$ of $\mathrm{MoO}_{3}$ before evaporating a $100 \mathrm{~nm}$ thick $\mathrm{Al}$ electrodes. The best cell characteristics with donor 1 shows a $\mathrm{V}_{\mathrm{oc}}=0.82 \mathrm{~V}, \mathrm{~J}_{\mathrm{sc}}=2.35 \mathrm{~mA} / \mathrm{cm}^{2}, \mathrm{FF}=58 \%$ and $\mathrm{PCE}=1.12 \%$, after a temperature annealing at $70^{\circ} \mathrm{C}$ as presented in Table 1 . The best cell characteristics with donor 2 shows a $\mathrm{V}_{\mathrm{oc}}=0.86 \mathrm{~V}, \mathrm{~J}_{\mathrm{sc}}=3.05 \mathrm{~mA} / \mathrm{cm} 2$, $\mathrm{FF}=60 \%$ and $\mathrm{PCE}=1.56 \%$ for ambient conditions. Thermal annealing improves only the cells based on Donor 1 . The $\mathrm{J}$ vs $\mathrm{V}$ characteristics of the best cells are presented in Figure 3. The external quantum efficiency (EQE) spectra of the best devices are illustrated in Figure 4. The EQE spectra indicate that both $\mathrm{C}_{60}$ and Donors 1 or 2 contribute to the photocurrent generation. 
Table 1. Inverted-bilayer solar cell electrical parameters using Donor 1.

\begin{tabular}{|c|c|c|c|c|c|}
\hline Cell Name & $\begin{array}{l}V_{\text {oc }} \\
\text { [V] }\end{array}$ & $\begin{array}{c}\mathrm{J}_{\mathrm{sc}} \\
{[\mathrm{mA} / \mathrm{cm} 2]}\end{array}$ & $\begin{array}{l}\mathrm{FF} \\
{[\%]}\end{array}$ & $\begin{array}{l}\mathrm{PCE} \\
{[\%]}\end{array}$ & $\begin{array}{c}\text { Average PCE } \\
{[\%]}\end{array}$ \\
\hline P1_ambient & 0.76 & 2.87 & 34.34 & 0.75 & 0.9 \\
\hline P2_ambient & 0.81 & 2.24 & 57.90 & 1.05 & \\
\hline $\mathrm{P} 1 \_50^{\circ} \mathrm{C}$ & 0.79 & 2.22 & 53.88 & 0.94 & 1.01 \\
\hline $\mathrm{P} 2-50^{\circ} \mathrm{C}$ & 0.81 & 2.27 & 58.74 & 1.08 & \\
\hline $\mathrm{P} 1 \_70^{\circ} \mathrm{C}$ & 0.81 & 2.18 & 55.94 & 0.99 & 1.06 \\
\hline P2_ $70^{\circ} \mathrm{C}$ & 0.82 & 2.35 & 58.32 & 1.12 & \\
\hline P1_90 $90^{\circ} \mathrm{C}$ & 0.83 & 2.36 & 56.81 & 1.11 & 1.04 \\
\hline $\mathrm{P} 2-90^{\circ} \mathrm{C}$ & 0.80 & 2.34 & 52.01 & 0.97 & \\
\hline $\mathrm{P} 1 \_110^{\circ} \mathrm{C}$ & 0.91 & 2.22 & 48.50 & 0.98 & 0.94 \\
\hline $\mathrm{P} 2-110^{\circ} \mathrm{C}$ & 0.81 & 2.20 & 50.77 & 0.90 & \\
\hline
\end{tabular}

Table 2. Inverted-bilayer solar cell electrical parameters using Donor 2.

\begin{tabular}{|c|c|c|c|c|c|}
\hline Cell Name & $\begin{array}{l}V_{o c} \\
{[V]}\end{array}$ & $\begin{array}{c}\mathrm{J}_{\mathrm{sc}} \\
{[\mathrm{mA} / \mathrm{cm} 2]}\end{array}$ & $\begin{array}{c}\mathbf{F F} \\
{[\%]}\end{array}$ & $\begin{array}{l}\text { PCE } \\
{[\%]}\end{array}$ & $\begin{array}{c}\text { Average PCE } \\
{[\%]}\end{array}$ \\
\hline P1_ambient & 0.85 & 3.07 & 57.65 & 1.51 & 1.54 \\
\hline P2_ambient & 0.86 & 3.05 & 59.81 & 1.56 & \\
\hline $\mathrm{P} 1 \_50^{\circ} \mathrm{C}$ & 0.86 & 2.96 & 55.04 & 1.39 & 1.40 \\
\hline $\mathrm{P} 2-50^{\circ} \mathrm{C}$ & 0.85 & 2.98 & 55.57 & 1.42 & \\
\hline P1_70 $\mathrm{C}$ & 0.85 & 2.49 & 58.02 & 1.22 & 1.26 \\
\hline $\mathrm{P} 22^{-} 70^{\circ} \mathrm{C}$ & 0.84 & 2.95 & 52.16 & 1.29 & \\
\hline
\end{tabular}
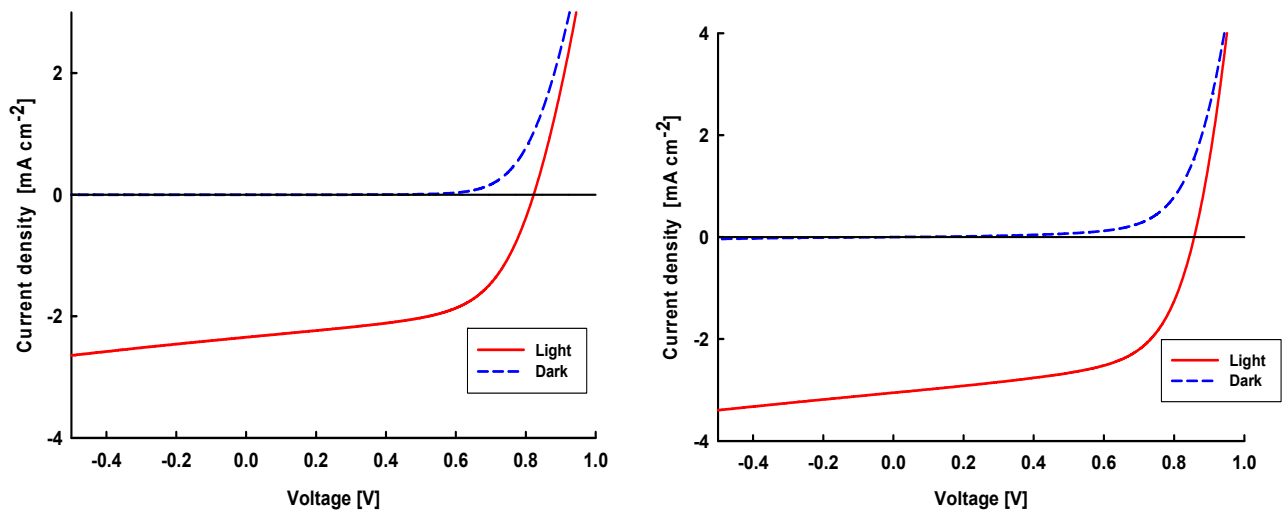

Figure 3. Current density vs voltage curves for best inverted-bilayer cell using Donor 1 (left) and Donor 2 (right). 

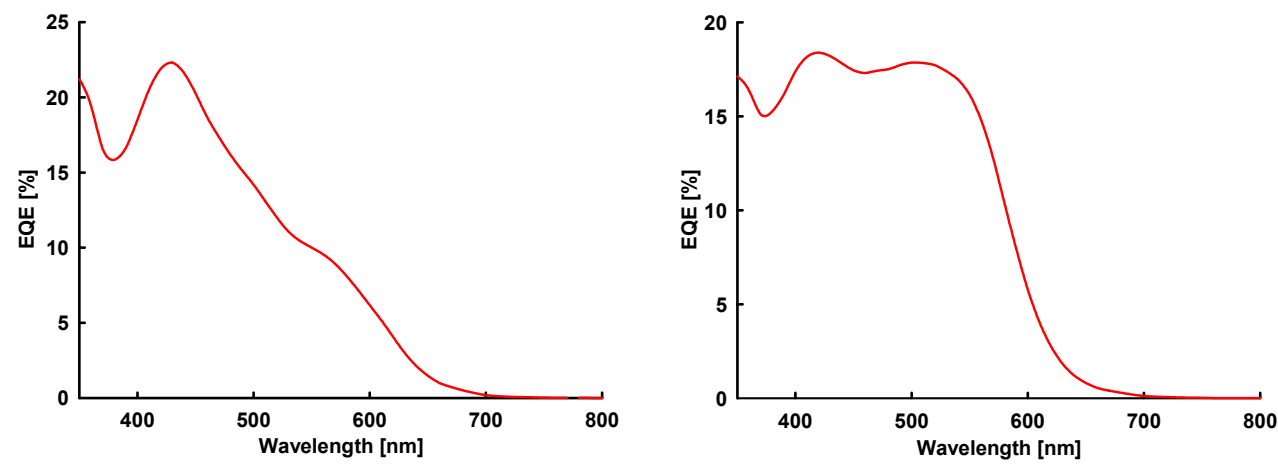

Figure 4. EQE characteristics for the best inverted-bilayer cell using Donor 1 (left) and Donor 2 (right).

\section{Inverted-BHJ structure (ITO/ZnO/Donor:PC $\left.{ }_{61} B M / M_{0} O_{3} / A I\right)$}

From our previous testing of donor 1 in direct BHJ cells the best D-A ratio in solution proved to be the 1:2. Thus, we proceed our experiments in inverted-BHJ structures with donor 1 using this $\mathbf{D}-\mathbf{A}$ ratio. The $\mathrm{ZnO}$ layer was kept at $30 \mathrm{~nm}$, the $\mathrm{MoO}_{3}$ at $10 \mathrm{~nm}$ and the Al electrodes at $100 \mathrm{~nm}$. The cell measurements results are presented in Table 3 . The thermal annealing at $70^{\circ} \mathrm{C}$ proves to be beneficial for this inverted structure too, pushing the PCE up to $1.71 \%$. The J-V and EQE characteristic for the best cells are presented in Figures 5,6 . In the case of donor 2 , in the absence of some previous $\mathrm{BHJ}$ tests, it was mandatory to discover the best D-A ratio. In the same fabrication stage, we tested out three $\mathbf{D}-\mathbf{A}$ ratios: $1: 1,1: 2$ and $1: 3$. The solar simulator measurements presented in Table 4, revealed that the best D-A ratio for donor 2 is 1:2, just as in the case of donor $\mathbf{1}$. The best cell characteristics for this ratio shows a $\mathrm{V}_{\mathrm{oc}}=0.97 \mathrm{~V}, \mathrm{~J}_{\mathrm{sc}}=5.54 \mathrm{~mA} / \mathrm{cm}^{2}, \mathrm{FF}=35 \%$ and $\mathrm{PCE}=1.85 \%$, in ambient conditions. Like in the case of the inverted-bilayer structure with the same donor thermal annealing does not improve the characteristics of the cells.

Table 3. Inverted-BHJ solar cell electrical parameters using Donor 1.

\begin{tabular}{|c|c|c|c|c|c|}
\hline Cell Name & $\begin{array}{l}V_{\text {oc }} \\
{[V]}\end{array}$ & $\begin{array}{c}\mathrm{J}_{\mathrm{sc}} \\
{\left[\mathrm{mA} / \mathrm{cm}^{2}\right]}\end{array}$ & $\begin{array}{l}\mathrm{FF} \\
{[\%]}\end{array}$ & $\begin{array}{l}\text { PCE } \\
{[\%]}\end{array}$ & $\begin{array}{c}\begin{array}{c}\text { Average PCE } \\
{[\%]}\end{array} \\
\end{array}$ \\
\hline P1_ambient & 0.44 & 4.90 & 30.41 & 0.66 & 1.14 \\
\hline P2_ambient & 1.02 & 4.88 & 32.71 & 1.63 & \\
\hline $\mathrm{P} 1 \_50^{\circ} \mathrm{C}$ & 1.02 & 4.88 & 32.72 & 1.63 & 1.35 \\
\hline $\mathrm{P} 2-50^{\circ} \mathrm{C}$ & 0.77 & 4.33 & 32.10 & 1.08 & \\
\hline $\mathrm{P} 1 \_70^{\circ} \mathrm{C}$ & 0.98 & 4.97 & 33.12 & 1.61 & 1.66 \\
\hline $\mathrm{P} 2{ }_{-} 70^{\circ} \mathrm{C}$ & 1.02 & 4.96 & 33.89 & 1.71 & \\
\hline P1_90 $90^{\circ} \mathrm{C}$ & 1.00 & 4.76 & 34.91 & 1.66 & 1.62 \\
\hline $\mathrm{P} 2-90^{\circ} \mathrm{C}$ & 0.99 & 4.60 & 34.69 & 1.59 & \\
\hline
\end{tabular}


GAVRIL-IONEL GIURGI, LORANT SZOLGA, ANDREEA CRIȘAN, ION GROSU, JEAN RONCALI

Table 4. Inverted-BHJ solar cell electrical parameters using Donor 2.

\begin{tabular}{|c|c|c|c|c|c|c|}
\hline $\begin{array}{l}\text { D-A } \\
\text { Ratio }\end{array}$ & Cell Name & $\begin{array}{l}\text { Voc } \\
\text { [V] }\end{array}$ & $\begin{array}{c}\mathrm{J}_{\mathrm{sc}} \\
{\left[\mathrm{mA} / \mathrm{cm}^{2}\right]}\end{array}$ & $\begin{array}{l}\mathrm{FF} \\
{[\%]}\end{array}$ & $\begin{array}{l}\mathrm{PCE} \\
{[\%]}\end{array}$ & $\begin{array}{c}\text { Average PCE } \\
\text { [\%] }\end{array}$ \\
\hline \multirow{6}{*}{$1: 1$} & P1_ambient & 1.02 & 4.05 & 34.68 & 1.43 & 1.44 \\
\hline & P2_ambient & 0.95 & 4.65 & 32.79 & 1.46 & \\
\hline & $\mathrm{P} 1 \_50^{\circ} \mathrm{C}$ & 0.87 & 4.44 & 34.46 & 1.33 & 1.34 \\
\hline & $\mathrm{P} 2=50^{\circ} \mathrm{C}$ & 0.86 & 4.56 & 34.15 & 1.35 & \\
\hline & P1_70 ${ }^{\circ} \mathrm{C}$ & 0.81 & 4.22 & 35.51 & 1.22 & 1.27 \\
\hline & $\mathrm{P} 2-70^{\circ} \mathrm{C}$ & 0.86 & 4.41 & 34.57 & 1.31 & \\
\hline \multirow{6}{*}{$1: 2$} & P3_ambient & 0.97 & 5.54 & 34.46 & 1.85 & 1.82 \\
\hline & P4_ambient & 0.97 & 5.40 & 34.13 & 1.79 & \\
\hline & P3_50 $50^{\circ} \mathrm{C}$ & 0.94 & 5.31 & 34.79 & 1.74 & 1.73 \\
\hline & $\mathrm{P} 4{ }^{-} 50^{\circ} \mathrm{C}$ & 0.88 & 5.51 & 35.48 & 1.72 & \\
\hline & P3 $70^{\circ} \mathrm{C}$ & 0.89 & 5.20 & 35.56 & 1.47 & 1.49 \\
\hline & $\mathrm{P} 4{ }_{-}^{-} 70^{\circ} \mathrm{C}$ & 0.75 & 5.47 & 37.25 & 1.52 & \\
\hline \multirow{6}{*}{$1: 3$} & P5_ambient & 0.99 & 4.42 & 38.14 & 1.67 & 1.65 \\
\hline & P6_ambient & 0.97 & 4.40 & 38.00 & 1.63 & \\
\hline & P5_50 ${ }^{\circ} \mathrm{C}$ & 0.93 & 4.23 & 38.93 & 1.54 & 1.50 \\
\hline & $P 6 \_50^{\circ} \mathrm{C}$ & 0.94 & 4.27 & 35.90 & 1.45 & \\
\hline & P5_70 $70^{\circ} \mathrm{C}$ & 0.90 & 4.28 & 37.04 & 1.43 & 1.41 \\
\hline & $P 6^{-}=70^{\circ} \mathrm{C}$ & 0.87 & 4.27 & 37.30 & 1.39 & \\
\hline
\end{tabular}
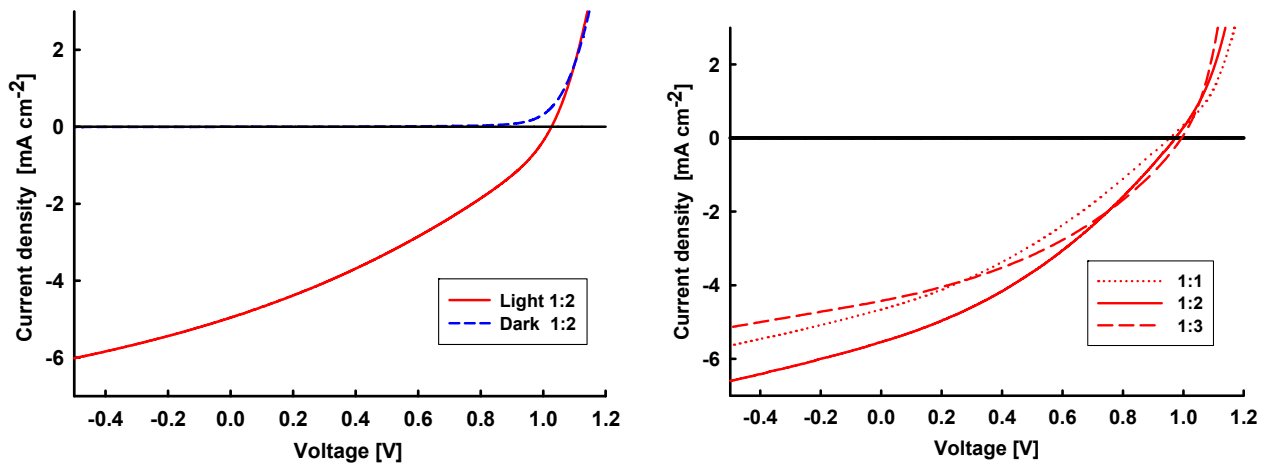

Figure 5. Current density vs voltage curves for best inverted-BHJ cells using Donor 1 (left) and Donor 2 (right). 

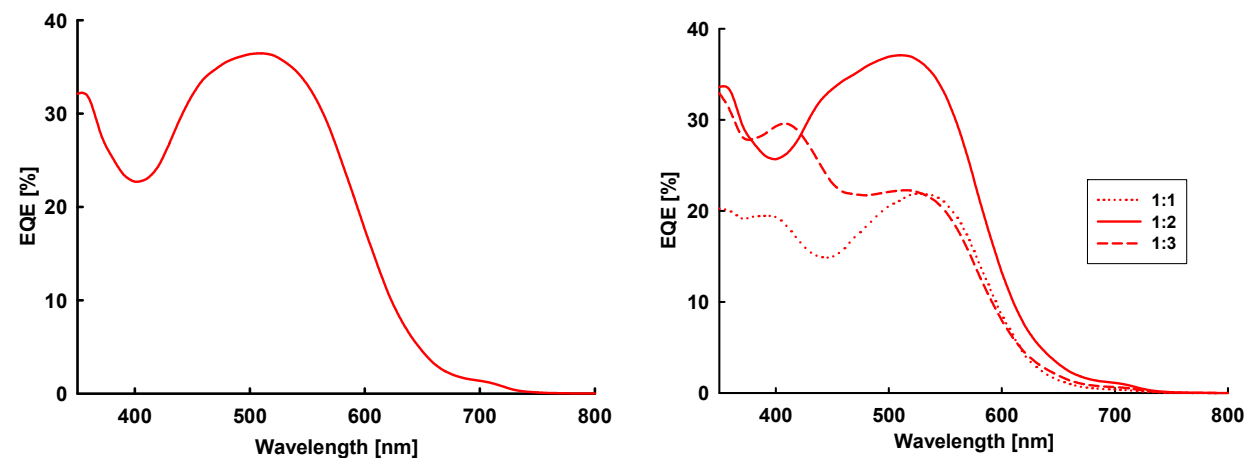

Figure 6. EQE characteristics for the best inverted-BHJ cell using Donor 1 (left) and Donor 2 (right).

\section{CONCLUSIONS}

A comparative analysis was conducted on the photovoltaic performances of bilayer and $\mathrm{BHJ}$ cells in inverted structures using two small molecular donors. Comparing the best cell properties from each structure reveals that the $\mathrm{BHJ}$ structures presents better electrical characteristics than bilayer cells. We were able to raise the PCE of the cells with donor 1 from $1.12 \%$ in the case of the inverted-bilayer structure up to $1.71 \%$ in the case of the inverted-BHJ structure and for the cells fabricated with donor 2 from $1.56 \%$ in inverted-bilayer structure to $1.85 \%$ in inverted-BHJ structure, thus showing that the hydroxymethyl group at the 3-position 3 of the thiophene unit does not improve cell characteristics. With both donors, inverted BHJs show higher current densities than inverted-bilayer structures, but low fill factors. This unwanted effect could be countered by further investigations using different buffer layers which can also further improve the PCE.

\section{EXPERIMENTAL PART}

\section{Materials and equipment}

The cells were obtained using commercially available ITO-coated glass substrates of $24 \times 25 \mathrm{~mm}$. These substrates were sonicated for 10 minutes in distilled water, cleaned with Deconex (10 $\mathrm{min})$, ethanol (10 min), isopropanol (10 min) and finally using an UV Ozone Cleaner for 20 minutes. 
$\mathrm{PC}_{61} \mathrm{BM}, \mathrm{PEDOT}, \mathrm{PSS}, \mathrm{MoO}_{3}, \mathrm{CHCl}_{3}, \mathrm{C}_{6} \mathrm{H}_{5} \mathrm{Cl}$ and $\mathrm{Al}$ were commercially available. The active material and $\mathrm{ZnO}$ were prepared accordingly to literature data. [18] The deposition of different layers of the cells were carried out either using a classic spin-coater or a high vacuum deposition equipment (MANTIS DEPOSITION- model QUBE). The characterization of the cells was performed with an Artificial Sun system LCS-100 (94011A-ES) and a monochromator equipment IQE 200B Quantum Efficiency Measurement Solution, while the thickness of the layers was measured using a profilometer Tencor AlphaStep D500. The absorption spectra of the film were analyzed by UV-VIS 1900 Shimadzu spectrometer

\section{General procedure for the fabrication of inverted BHJs}

A layer of $40 \mathrm{~nm} \mathrm{ZnO}$ was deposited by spin-casting [S = $3000 \mathrm{rpm}$, $\mathrm{t}=40 \mathrm{~s}$ ) on clean ITO plates and then the plates were heated at $200^{\circ} \mathrm{C}$ for $10 \mathrm{~min}$. The films of donor: $\mathbf{P C}_{61} \mathbf{B M}$ were spun-cast $\left(\mathrm{t}_{1}=40 \mathrm{~s}, \mathrm{~S}_{1}=1000\right.$ $\mathrm{rpm}, \mathrm{t}_{2}=20 \mathrm{~s}, \mathrm{~S}_{2}=8000 \mathrm{rpm}$ ) on top of $\mathrm{ZnO}$ layer. The hole transporter layer (HTL) consisting in a $10 \mathrm{~nm}$ thick $\mathrm{MoO}_{3}$ layer and the $\mathrm{Al}$ electrodes $(100 \mathrm{~nm})$ were deposited by thermal evaporation under high vacuum at $10^{-6}$ mbar.

\section{ACKNOWLEDGEMENTS}

This work was supported by a grant of the Romanian Ministry of Education and Research, CCCDI - UEFISCDI, project number PN-III-P22.1-PED-2019-2601 "REGRENPOS" within PNCDI III.

\section{REFERENCES}

[1] S. Günes,H. Neugebauer, N. S. Sariciftci, Chem. Rev. 2007,107, 1324-1338.

[2] C. J. Brabec, S. Gowrisanker, J. J. M. Halls, D. Laird, S. Jia, S. P. Williams, Adv. Mater. 2010, 22, 3839-3856.

[3] P. Peumans, A. Yakimov, S.R. Forrest, J. Appl. Phys. 2003, 93, 3693-3723.

[4] K. Walzer, B. Maennig, M. Pfeiffer, K. Leo, Chem. Rev. 2007, 107, 1223-1270.

[5] G.-I. Giurgi, L. Szolga, I. Kovacs, E. Bogdan, N.D. Hădade, A. Terec, I. Grosu, J. Roncali, Studia UBB Chemia, 2020, 2, 95-106.

[6] M. Abdallaoui, N. Sengouga, A. Chala, A.F. Meftah, \& A. M. Meftah, Opt.Mater., 2020, 105, 109916.

[7] S. Huang, B. Kang, L. Duan, \& D. Zhang, Colloid.Interface Sci., 2020, 583, 178187.

[8] Y. Wang, H. Cong, B. Yu, Z. Zhang, \& X. Zhan, Mater., 2017, 10, 1064.

[9] A. Mishra, P. Bäuerle Angew. Chem. Int. Ed. 2012, 51, 2020-2068. 
[10] J. Roncali, P. Leriche, P. Blanchard Adv. Mater. 2014, 26, 3821.

[11] D. Collins, N. A. Ran, M. C. Heiber, T.-Q. Nguyen, Adv. Energy Mater. 2017, 1602242.

[12] A. Venkateswararao, K.-T. Wong, Bull Chem. Soc. Jpn. 2021, 94, 812-837.

[13] D. Demeter, S. Mohamed, A. Diac, I. Grosu, J. Roncali, ChemSusChem, 2014, 7, 1046-1050.

[14] J. Roncali, Acc. Chem. Res. 2009, 42, 1719-1730.

[15] A.P. Diac, L. Szolga, C. Cabanetos, A. Bogdan, A. Terec, I. Grosu, J. Roncali, Dyes Pigm., 2019, 171, nr. 107748.

[16] A. Bogdan,L. Szolga, G.-I. Giurgi, A.P. Crişan, D. Bogdan, S. Hadsadee, S. Jungsuttiwong, R. Po, I. Grosu, J. Roncali, Dyes Pigm., 2021, 184, 108845.

[17] S. Mohamed, D. Demeter, J.-A. Laffitte, P. Blanchard, J. Roncali, SciRep 2015, 5, nr. 9031.

[18] M.I Nan, E. Lakatos, G.-I. Giurgi, L. Szolga, R. Po, A Terec, S. Jungsuttiwong I. Grosu, J. Roncali, Dyes Pigm., 2020, 181, 108527.

[19] Y. M. Sun, J. H. Seo, C. J. Takacs, J. Seifter, A. J. Heeger, Adv. Mater, 2011, 23, 1679-1683. 
